Available online at:

http://journal.unila.ac.id/index.php/tropicalsoil

DOI: $10.5400 /$ jts.2019.v24i1

\title{
Soil Microbial Activity and Diversity in Response to Soil Chemical Factors in Agricultural Soils
}

\author{
Lily Ishak ${ }^{* 1}$ and Philip Hugh Brown ${ }^{2}$ \\ ${ }^{1}$ Department of Soil Science, Faculty of Agriculture, Universitas Khairun, Jl. Raya Kampus Unkhair Gambesi \\ Ternate, North Maluku 97719, Indonesia, Phone/Fax: +62921311 0905/+629213110901 \\ ${ }^{2}$ School of Medical and Applied Sciences, Central Queensland University, University Drive, Bundaberg Campus, \\ QLD 4670, Australia, *e-mail: Lily_ishak@yahoo.com
}

Received August 30, 2018; Revised November 12, 2018; Accepted January 7, 2019

\begin{abstract}
The role of microbial communities in maintaining soil health is mostly influenced by chemical condition of soil. Microbial communities vary in response to soil chemical factors. The contradictive results from previous findings emphasise that it is difficult to define a pattern of the influence of soil chemical factors on soil microbial diversity and activity. The aim of the study was to assess soil microbial responses to soil chemical factors in agricultural soils. Composite soil (Dermosol order) samples taken from 16 commercial crop sites in Bundaberg, Queensland, Australia, were chemically and biologically analysed. It was found that bacterial and fungal activity and diversity were significantly affected by soil $\mathrm{EC}, \mathrm{SOM}$ and $\mathrm{NO}_{3}-\mathrm{N}$ content, but were not influenced by soil $\mathrm{pH}, \mathrm{CEC}$, and $\mathrm{Ca}: \mathrm{Mg}$ ratio. The diversity of bacterial and fungal communities displayed a positive linear relationship with soil $\mathrm{EC}$, whereas the activity and diversity of these two microbial groups and SOM displayed a significant quadratic relationship. The finding suggested that microbial community was predominantly influenced by SOM content.
\end{abstract}

Keywords: Agricultural soils, CLPP, soil chemical factors, soil microbial activity and diversity

\begin{abstract}
ABSTRAK
Peran komunitas mikroba dalam memelihara kesehatan tanah dipengaruhi oleh kondisi kimia tanah. Respon komunitas mikroba terhadap faktor-faktor kimia tanah sangat berivariasi. Beberapa penelitian sebelumnya menunjukkan hasil yang kontradiktif, sehingga sulit mendefinisikan suatu pola pengaruh faktor kimia tanah terhadap aktivitas dan keragaman mikroba tanah. Tujuan dari penelitian ini adalah untuk menganalisis respon dari mikroba tanah terhadap faktor-faktor kimia tanah pada tanah-tanah pertanian. Sampel tanah dari ordo Dermosol diambil secara komposit dari 16 lokasi pertanian di wilayah Bundaberg, Queensland, Australia, untuk dianalisis komponen kimia dan biologinya. Hasil penelitian menunjukkan bahwa aktivitas dan keragaman bakteri dan cendawan sangat dipengaruhi oleh konduktivitas elektrik tanah, bahan organik tanah (BOT), dan $\mathrm{NO}_{3}-\mathrm{N}$ tanah, namun lemah sekali atau tidak dipengaruhi oleh $\mathrm{pH}$ tanah, kapasitas tukar kation, dan rasio $\mathrm{Ca}: \mathrm{Mg}$ tanah. Keragaman komunitas bakteri dan cendawan menunjukkan hubungan linear positif dengan konduktivitas elektrik, sementara aktivitas dan keragaman kedua kelompok mikroba ini menunjukkan hubungan kuadratik dengan BOT. Hasil penelitian menyimpulkan bahwa komunitas mikroba tanah sangat dipengaruhi oleh kandungan BOT.
\end{abstract}

Kata kunci: Aktivitas dan keragaman mikroba tanah, CLPP, faktor kimia tanah, tanah-tanah pertanian

\section{INTRODUCTION}

Bacterial and fungal functional groups play an important role in a wide range of soil functions including soil-borne disease suppression (Nannipieri and Badalucco 2003; Coleman et al. 2004). As

J Trop Soils, Vol. 24, No. 1, 2019: 43-51

ISSN 0852-257X; E-ISSN 2086-6682 soil health is manifest of the maintenance of soil functions (Lal 2011), the role of soil microbial communities in the maintenance of soil health cannot be ignored. This implies that the capacity of healthy soils to sustain soil biota and plant life through the maintenance of a wide range of soil biochemical processes and soil-borne disease suppression (Doran and Zeiss 2000) depends on the viability of soil microbial communities, and their diversity and 
activity (Lange et al. 2014). Yet, the size, activity and diversity of microbial community is influenced by soil factors including soil chemical components (Brennan and Acosta-Martinez 2017).

Soil chemical factors are thought to influence diversity of soil microbial communities and their activity in disease suppression (Haggag 2002; Heyman et al. 2007). Studies on the effects of soil chemical factors on microbial community have included investigation of components including SOM, soil $\mathrm{C}$ and $\mathrm{N}$, and $\mathrm{pH}$ which are regarded as the most important factors influencing the activity and diversity of soil microbial community (Cookson et al. 2008; Lauber et al. 2008; Jordi Garcia-Pausas and Paterson 2011; Lupwayi et al. 2012). In relation to nutrient effects, several studies have found that soil microbial activity is associated with the availability of calcium $(\mathrm{Ca})$ particularly in regulating disease suppression, in which $\mathrm{Ca}$ concentration in soil showed a strong negative correlation with disease onset (Falcon, Fox and Trujillo 1984; Heyman et al. 2007). Yet, the availability of $\mathrm{Ca}$ and other nutrients like $\mathrm{P}$ are $\mathrm{pH}$ limited (Falcon et al. 1984), so interactions between soil $\mathrm{pH}$ and nutrient effects are likely to make interpretation of data quite complex. In addition, soils high in fertility and nutrient availability favour bacterial community, while low fertility and nutrient availability favour fungal community (Grayston et al. 2004). However, contradictory results of studies have been published (Fierer and Jackson 2006; Stark et al. 2008; Tu et al. 2014), suggesting the characteristics of soil chemical factors and microbial community relationships are still poorly understood.

The effects of soil chemical factors on soil microbial communities are likely to be very complex (Whalley et al. 1995). In order to gain deeper understanding on the relationships between these two soil components, the present study was undertaken to assess the differences in response of soil microbial communities to different chemical properties of agricultural soils. It was hypothesised that different soil microbial communities would inhabit soils with different chemical properties.

\section{MATERIALS AND METHODS}

\section{Field Investigation and Study Sites}

An investigation to examine the relationship between soil microbial activity and diversity and soil chemical factors is required to provide further information on the changes of soil microbial activity and diversity in soils under different chemical characteristics. Soil chemical factors chosen for this investigation are soil $\mathrm{pH}$, electrical conductivity (EC), soil organic matter $(\mathrm{SOM})$, nitrate $\left(\mathrm{NO}_{3}-\mathrm{N}\right)$, cation exchange capacity (CEC), and calcium:magnesium ratio $(\mathrm{Ca}: \mathrm{Mg})$, whilst soil microbial properties are indicated by catabolic activity and functional diversity.

The experiment involved collection of soil samples from 16 commercial crop sites in the Bundaberg region, QLD, Australia, in April 2015. The soils were classified by Australian Soil Classification as Dermosol (Isbel 1997). Samples were taken from the field that had capsicum crops grown in rotation with other vegetable crops for one or more years. At each site, soil samples were collected from the root zone of capsicum plants at $15 \mathrm{~cm}$ depth with a soil corer (5 $\mathrm{cm}$ in diameter) and bulked.

\section{Soil Chemical Analyses}

Soil chemical properties of the soils from 16 locations were analysed in the laboratory. Total soil carbon $(\mathrm{C})$ content and total soil nitrogen $(\mathrm{N})$ content were analysed after dry combustion using a CNS2000 analyser (LECO Corporation, St. Joseph, MI, USA). Soil organic matter content was calculated by multiplying the percentage of total $\mathrm{C}$ with 1.724 factor (Nelson and Sommers 1982). Soil pH was measured using a suspension of 1:5 soil:water ratio (McLean 1982). Electrical conductivity was determined using a suspension of 1:5 soil:water ratio (McLean 1982). Cation exchange capacity and exchangeable cations $\left(\mathrm{Ca}^{2+}, \mathrm{Mg}^{2+}, \mathrm{K}^{+}\right.$, and $\left.\mathrm{Na}^{+}\right)$ were analysed with ammonium acetate method ( $1 \mathrm{~N}$ $\mathrm{NH}_{4} \mathrm{OAc}$ at $\mathrm{pH}$ 7.0) (Thomas 1982).

\section{Soil Biological Assessment}

Soil biological properties were analysed using community level physiological profiles (CLPP) method. Soil bacterial and fungal activity and diversity were assessed to measure soil microbial responses to the effect of soil chemical characteristics from 16 different locations. Soil bacterial activity and diversity was analysed using the Biolog Eco-Plates ${ }^{\mathrm{TM}}$, whilst the Biolog FF-plate was utilised for analysing activity and diversity of fungal community. For the analysis of soil bacterial activity and diversity, three replicates per soil sample from 16 locations were used. Meanwhile, analysis of fungal activity and diversity was held for soil samples from 16 locations with one replicate per soil sample.

The CLPP method principally involves direct inoculation of soil samples into Biolog microtitre plates, incubation, and spectrometric detection on 
heterotrophic microbial activity (Insam and Goberna, 2004). For microbial cell extraction, a $10 \mathrm{~g}$ fresh soil sample was suspended with a $100 \mathrm{~mL}$ of sterile saline solution $(\mathrm{NaCl})(0.85 \%, \mathrm{w} / \mathrm{v})$ in a $250 \mathrm{~mL}$ schott bottle. Saline solution was made by dissolving $4.25 \mathrm{~g}$ of $\mathrm{NaCl}$ in $500 \mathrm{ml}$ of distilled water to prepare $0.85 \%$ saline solution and then sterilising the solution, together with all transfer equipment and glassware prior to use, in autoclave at $121^{\circ} \mathrm{C}$ for $16 \mathrm{~min}$. The soil suspension was then shaken using a rotary shaker at $200 \mathrm{rpm}$ for $1 \mathrm{~h}$ at a room temperature of $25^{\circ} \mathrm{C}$. The suspension was allowed to settle for 11 $\mathrm{h}$ before inoculation to allow utilisation of any soluble organic compounds from the soil by soil microbia. Then, a $5 \mathrm{ml}$ of the suspension was diluted 10 -fold with $45 \mathrm{~mL}$ of sterile deionised water to make a 50 $\mathrm{mL}$ final volume. The final aliquot with 1000 -fold dilution was used for inoculation. The protocols outlined above are also used for performing fungal extraction except the aliquots must contain antibiotics (10 $\mu \mathrm{g}$ streptomycin and $1.5 \mu \mathrm{g}$ tetracycline per a $100 \mu \mathrm{L}$ of a microtiter-plate well) to limit the growth of bacteria (modified from Classen et al. (2003). A $150 \mu \mathrm{L}$ of 1000 -fold diluted solutions were inoculated into each well of the Biolog Eco-Plates containing 31 different $\mathrm{C}$ sources and one non-substrate (water) solution in triplicates for bacterial inoculations, while $100 \mu \mathrm{L}$ per well was used in the FF plates containing 96 different carbon sources for fungal inoculation. After filling all the wells with the diluted solution, initial reading was taken using a spectrophotometer plate reader at $590 \mathrm{~nm}$ wavelength for bacterial Eco-Plates and $750 \mathrm{~nm}$ for fungal FF plates. The inoculated Eco-Plates were then incubated at $30^{\circ} \mathrm{C}$ and $\mathrm{FF}$ plates at $26^{\circ} \mathrm{C}$ in the dark. The microplates were monitored at $24 \mathrm{~h}$ intervals for 7 days $(0,24,48,72,96,120,144,168$ h) for bacteria and fungi.

\section{Statistical Analyses}

Regression analyses (linear and quadratic models) were used to determine any relationships between soil bacterial and fungal activity and diversity and soil chemical components in 16 locations. Analyses were performed using Minitab version 16.

\section{RESULTS AND DISCUSSION}

\section{Soil Bacterial and Fungal Activity in Response to Soil Chemical Factors}

Soil bacterial and fungal CLPP were compared among the treatments using several soil chemical

Table 1. Chemical and biological properties of soil samples taken from 16 different sites at the Bundaberg region, QLD.

\begin{tabular}{|c|c|c|c|c|c|c|c|c|c|c|}
\hline \multirow{3}{*}{ Site } & \multicolumn{6}{|c|}{ Soil chemical properties } & \multicolumn{4}{|c|}{ Soil Biological properties } \\
\hline & \multirow[b]{2}{*}{$\mathrm{pH}$} & \multirow{2}{*}{$\begin{array}{c}\mathrm{EC} \\
\left(\mathrm{dS} \mathrm{m}^{-1}\right)\end{array}$} & \multirow[b]{2}{*}{$\begin{array}{c}\text { SOM } \\
(\%)\end{array}$} & \multirow[b]{2}{*}{$\begin{array}{l}\mathrm{NO}_{3}-\mathrm{N} \\
\left(\mathrm{mgL}^{-1}\right)\end{array}$} & \multirow{2}{*}{$\begin{array}{c}\text { CEC } \\
\left(\text { meq } 100 \mathrm{~g}^{-1}\right)\end{array}$} & \multirow{2}{*}{$\begin{array}{c}\text { Ca:Mg } \\
\text { ratio }\end{array}$} & \multicolumn{2}{|c|}{ Microbial activity } & \multicolumn{2}{|c|}{ Microbial diversity } \\
\hline & & & & & & & $\begin{array}{c}\text { Bacteria } \\
\left(\text { AWCD*) }^{*}\right)\end{array}$ & $\begin{array}{c}\text { Fungi } \\
\text { (Turbidity) }\end{array}$ & Bacteria & Fungi \\
\hline$\# 1$ & 6.0 & 0.12 & 5.52 & 24 & 9.99 & 2.47 & 1.73 & 0.42 & 3.32 & 3.1 \\
\hline$\# 2$ & 5.4 & 0.06 & 3.63 & 15 & 7.47 & 4.16 & 0.61 & 0.29 & 2.88 & 2.2 \\
\hline$\# 3$ & 6.4 & 0.09 & 12.17 & 11 & 23.46 & 2.05 & 0.52 & 0.02 & 2.71 & 1.9 \\
\hline \#4 & 5.4 & 0.07 & 2.84 & 17 & 3.71 & 2.43 & 1.65 & 0.18 & 3.28 & 1.2 \\
\hline$\# 5$ & 5.6 & 0.1 & 7.74 & 24 & 7.57 & 4.79 & 1.52 & 0.31 & 3.30 & 2.2 \\
\hline \#6 & 7.2 & 0.09 & 7.44 & 24 & 8.35 & 4.62 & 0.78 & 0.43 & 3.22 & 2.4 \\
\hline \#7 & 5.9 & 0.1 & 7.26 & 20 & 8.32 & 6.63 & 1.74 & 0.28 & 2.79 & 2.2 \\
\hline$\# 8$ & 5.5 & 0.06 & 4.44 & 12 & 5.33 & 5.06 & 1.05 & 0.11 & 3.16 & 0.9 \\
\hline \#9 & 5.6 & 0.1 & 4.8 & 28 & 6.01 & 3.23 & 1.68 & 0.25 & 3.28 & 1.9 \\
\hline$\# 10$ & 5.9 & 0.09 & 4.64 & 9 & 5.64 & 1.99 & 2.04 & 0.16 & 3.33 & 1.3 \\
\hline$\# 11$ & 5.8 & 0.04 & 3.69 & 8 & 6.39 & 3.21 & 0.42 & 0.02 & 2.42 & 0.6 \\
\hline \#12 & 5.8 & 0.07 & 4.15 & 16 & 9.24 & 2.97 & 0.24 & 0.06 & 3.30 & 0.6 \\
\hline$\# 13$ & 6.4 & 0.09 & 12.17 & 11 & 23.46 & 2.05 & 1.18 & 0.20 & 3.25 & 1.8 \\
\hline$\# 14$ & 5.7 & 0.09 & 2.66 & 14 & 24.53 & 3.48 & 0.57 & 0.01 & 2.58 & 0.4 \\
\hline$\# 15$ & 6.3 & 0.13 & 8.67 & 21 & 34.3 & 1.85 & 1.38 & 0.22 & 3.25 & 1.9 \\
\hline$\# 16$ & 6.6 & 0.07 & 3.96 & 5 & 41.29 & 1.89 & 0.81 & 0.03 & 3.03 & 0.5 \\
\hline
\end{tabular}

Note: *AWCD = Average well color development. 
components resulted from laboratory analyses (Table 1). Bacterial activity (determined by the values of AWCD at $72 \mathrm{~h}$ of incubation time) was significantly related to $\mathrm{EC}(p=0.000), \operatorname{SOM}(p=$ $0.012)$, and $\mathrm{NO}_{3}-\mathrm{N}(p=0.005)$. A quadratic model most accurately represented the relationship between bacterial activity and SOM, although the model fitting was quite weak with $\mathrm{R}^{2}$ values of 0.18 . Linear models were the most accurate representation of the positive relationship between bacterial activity and $\mathrm{EC}$ and $\mathrm{NO}_{3}-\mathrm{N}$, although the relationships were also weak with $\mathrm{R}^{2}$ values of 0.30 and 0.16 , respectively (Table 2 ). There were no significant relationships between the activity of the bacterial communities and soil $\mathrm{pH}, \mathrm{SOC}, \mathrm{CEC}$, and $\mathrm{Ca}: \mathrm{Mg}$ ratio with the values of $p>0.05$.

Fungal activity (determined by the values of turbidity at $72 \mathrm{~h}$ of incubation time) was significantly related to SOM $(p=0.023), \mathrm{NO}_{3}-\mathrm{N}(p=0.001)$ and $\mathrm{EC}(p=0.043)$, whereas the relationships between fungal activity and soil $\mathrm{pH}, \mathrm{EC}, \mathrm{SOC}, \mathrm{CEC}$ and $\mathrm{Ca}: \mathrm{Mg}$ ratio were not significant $(p>0.05)$. Similar to bacteria, the relationship between fungal activity and SOM was mostly accurately represented in a quadratic model, although the relationship was fairly weak with $\mathrm{R}^{2}$ value of 0.44 , whereas the positive relationships between fungal activity and $\mathrm{NO}_{3}-\mathrm{N}$ and $\mathrm{EC}$ were accurately represented in linear models, although the relationships were weak with the $\mathrm{R}^{2}$ values of 0.59 and 0.26 , respectively (Table 2 ).

A weak positive relationship was shown between bacterial activity and $\mathrm{EC}(\mathrm{Y}=-0.0647+$ 13.86X, $\mathrm{R}^{2}=0.14$ ) (Figure 1), and between fungal activity and $\mathrm{EC}\left(\mathrm{Y}=-0.077+3.096 \mathrm{X}, \mathrm{R}^{2}=0.26\right)$ (Figure 2). At the lowest level of EC $\left(0.04 \mathrm{dS} \mathrm{m}^{-1}\right)$, bacterial activity and fungal activity in soil were lower, indicated by the AWCD value of less than 0.5 absorbance level (abs.) units for bacterial community and less than 0.1 abs. units for fungal community. The activity of bacteria increased slowly to the level between 1.5 and 2.0 abs. units when the level of EC increased up to $0.13 \mathrm{dS} \mathrm{m}^{-1}$, whereas fungal activity increased sharply to the level of 0.3 abs. units when EC value increased up to $0.13 \mathrm{dS}$ $\mathrm{m}^{-1}$.

A quadratic relationship was observed between bacterial activity and SOM ( $\mathrm{Y}=-0.25+0.44 \mathrm{X}-$ $0.03 \mathrm{X}^{2}, \mathrm{R}^{2}=0.18$ ) (Figure 1), and between fungal activity and $\mathrm{SOM}\left(\mathrm{Y}=-0.336+0.167 \mathrm{X}-0.011 \mathrm{X}^{2}\right.$, $\mathrm{R}^{2}=0.44$ ) (Figure 2). Soils containing lower levels of SOM had lower bacterial and fungal activity. Activity of these two functional groups increased and reached a peak when SOM content was at a level between $6 \%$ and $8 \%$. Beyond $8 \%$ SOM, the activity of these two groups declined again.

A positive linear relationship was also observed between bacterial activity and $\mathrm{NO}_{3}-\mathrm{N}(\mathrm{Y}=0.56+$

Table 2. Regression models predicting bacterial and fungal activity as a function of soil chemical characteristics.

\begin{tabular}{lccccc}
\hline \multirow{2}{*}{ Variable } & \multicolumn{2}{c}{ Bacteria } & \multicolumn{2}{c}{ Fungi } & \multirow{2}{*}{ Regression Model tested } \\
\cline { 2 - 5 } & $\mathrm{R}^{2}$ & $p$ & $\mathrm{R}^{2}$ & $p$ & Quadratic \\
\hline Soil $\mathrm{pH}$ & 0.05 & 0.346 & 0.17 & 0.304 & Linear \\
$\mathrm{EC}\left(\mathrm{dS} \mathrm{m}{ }^{-1}\right)$ & 0.30 & 0.0001 & 0.26 & 0.043 & Quadratic \\
$\mathrm{SOM}(\%)$ & 0.18 & 0.012 & 0.44 & 0.023 & Linear \\
$\mathrm{NO}_{3}-\mathrm{N}\left(\mathrm{mg} \mathrm{L}^{-1}\right)$ & 0.16 & 0.005 & 0.59 & 0.001 & Linear \\
$\mathrm{CEC}\left(\mathrm{meq} \mathrm{100} \mathrm{g}^{-1}\right)$ & 0.06 & 0.093 & 0.14 & 0.155 & Linear \\
$\mathrm{Ca}: \mathrm{Mg} \mathrm{ratio}$ & 0.001 & 0.805 & 0.12 & 0.182 & \\
\hline
\end{tabular}

Note: $\mathrm{R}^{2}=$ the coefficient of determination; $p$-value = calculated probability.

Table 3. Regression models predicting bacterial and fungal diversity (Shannon index) as a function of soil chemical characteristics.

\begin{tabular}{|c|c|c|c|c|c|}
\hline \multirow{2}{*}{ Variable } & \multicolumn{2}{|c|}{ Bacteria } & \multicolumn{2}{|c|}{ Fungi } & \multirow[b]{2}{*}{ Regression Model tested } \\
\hline & $\mathrm{R}^{2}$ & $p$ & $\mathrm{R}^{2}$ & $p$ & \\
\hline Soil pH & 0.02 & 0.637 & 0.05 & 0.727 & Quadratic \\
\hline $\mathrm{EC}\left(\mathrm{dS} \mathrm{m} \mathrm{m}^{-1}\right)$ & 0.15 & 0.006 & 0.39 & 0.010 & Linear \\
\hline SOM (\%) & 0.14 & 0.030 & 0.47 & 0.016 & Quadratic \\
\hline $\mathrm{NO}_{3}-\mathrm{N}\left(\mathrm{mg} \mathrm{L}^{-1}\right)$ & 0.16 & 0.005 & 0.45 & 0.005 & Linear \\
\hline $\mathrm{CEC}\left(\right.$ meq $\left.100 \mathrm{~g}^{-1}\right)$ & 0.02 & 0.350 & 0.05 & 0.401 & Linear \\
\hline $\mathrm{Ca}: \mathrm{Mg}$ ratio & 0.03 & 0.218 & 0.04 & 0.451 & Linear \\
\hline
\end{tabular}



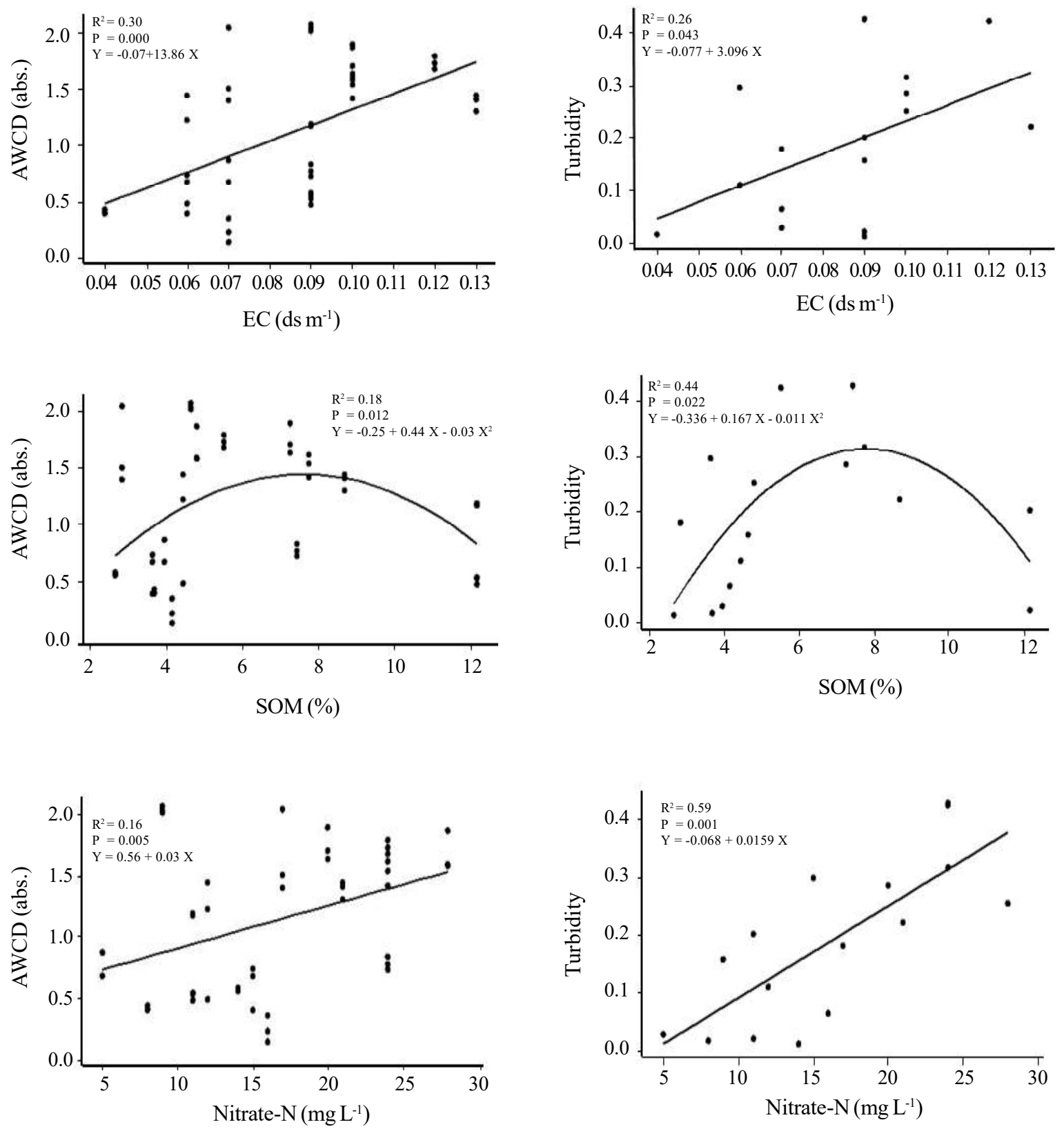

Figure 1. The relationships between EC, SOM, Nitrate- $\mathrm{N}$ and bacterial activity with statistical significance of $p<0.05$.

$\left.0.03 \mathrm{X}, \mathrm{R}^{2}=0.16\right)$ (Figure 1), and between fungal activity and $\mathrm{NO}_{3}-\mathrm{N}\left(\mathrm{Y}=-0.068+0.0159 \mathrm{X}, \mathrm{R}^{2}=\right.$ 0.59 ) (Figure 2). Soils with lower $\mathrm{NO}_{3}-\mathrm{N}$ content had lower bacterial and fungal activity. Activity of bacteria and fungi increased when the level of $\mathrm{NO}_{3}$ $\mathrm{N}$ increased.

\section{Soil Bacterial and Fungal Diversity in Response to Soil Chemical Factors}

The regression analyses using CLPP data revealed a significant relationship between bacterial diversity and EC $(p=0.006)$, SOM $(p=0.030)$,

Figure 2. The relationships between EC, SOM, Nitrate-N and fungal activity with statistical significance of $p<0.05$.

and $\mathrm{NO}_{3}-\mathrm{N}(p=0.005)$. Bacterial diversity was not significantly correlated to soil $\mathrm{pH}, \mathrm{SOC}, \mathrm{CEC}$, and $\mathrm{Ca}: \mathrm{Mg}$ ratio with $p>0.05$. A similar pattern was observed when assessing fungal diversity, which showed a significant relationship with EC $(p=0.010)$, SOM $(p=0.016)$, and $\mathrm{NO}_{3}-\mathrm{N}(p=0.005)$. Significant relationships between bacterial and fungal diversity and SOM were best described by quadratic models, whereas significant relationships between $\mathrm{EC}$ and bacterial and fungal diversity and between $\mathrm{NO}_{3}-\mathrm{N}$ and bacterial and fungal diversity were best described using linear models (Table 3 ). 

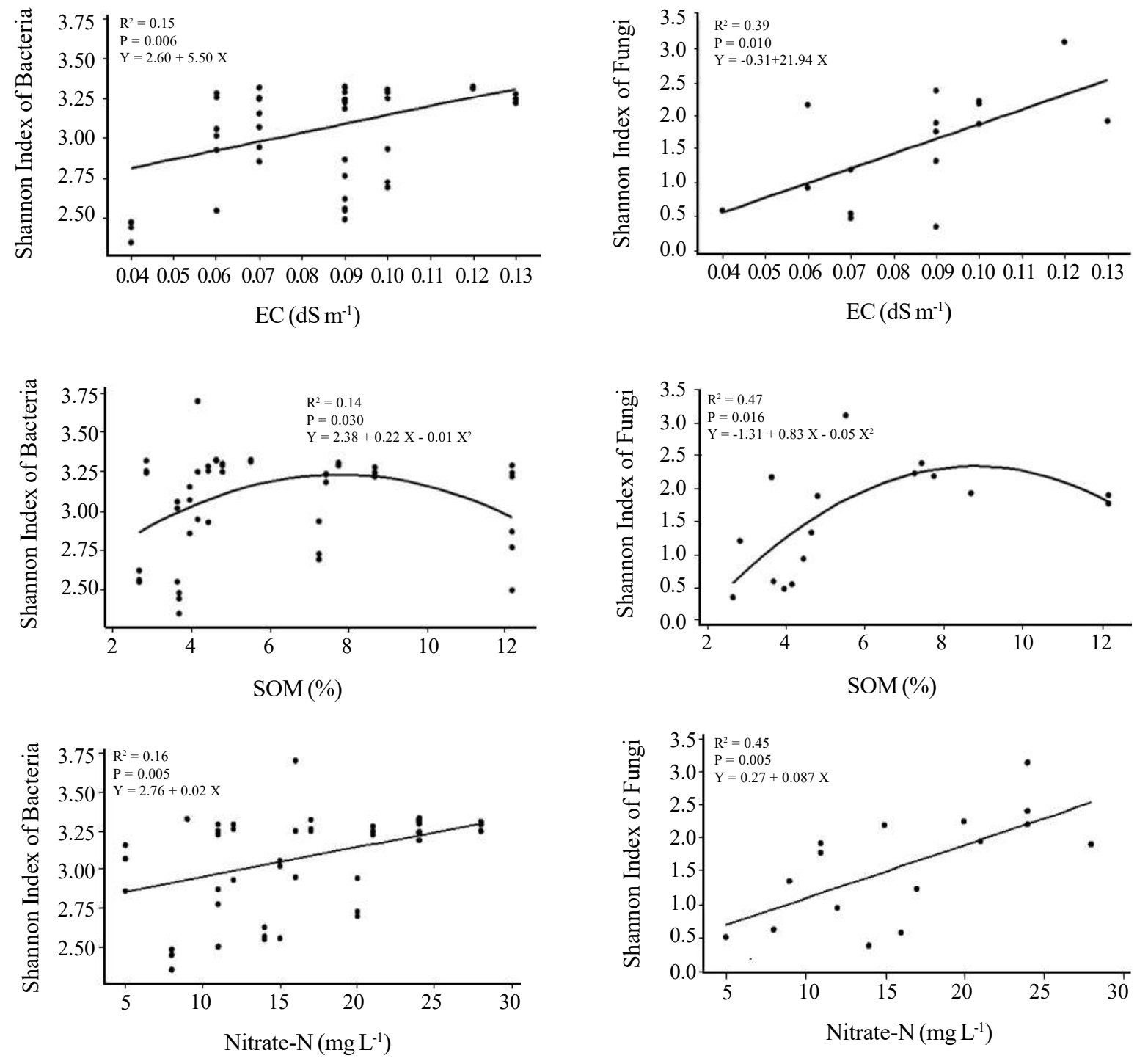

Figure 3. The relationships between EC, SOM, Nitrate-N and bacterial diversity with statistical significance of $p<0.05$.

The values of EC across the 16 sites were below 0.15 which were categorised as low and reflecting that the soils are non-saline (Cass 1998). Despite being low in EC content, bacterial and fungal diversity varied in the 16 soils. At the lowest EC $\left(0.04 \mathrm{dS} \mathrm{m}^{-1}\right)$ bacterial diversity was also low $(\mathrm{H}<$ $2.50)$ in soil. Bacterial diversity increased progressively as the level of EC in soil increased (Figure 3). Similarly, fungal diversity was lower (H $=0.5$ ) in soils with a lower EC. The diversity of the fungal community continuously increased by fivefold as the EC increased up to $0.13 \mathrm{dS} \mathrm{m}^{-1}$ (Figure $4)$.

In relation to the availability of SOM, bacterial diversity was moderate $(2.50<\mathrm{H}<3.0)$ at lower

SOM content of between $2 \%$ and $4 \%$. When SOM level was between $6 \%$ and $8 \%$, the diversity of bacteria gradually increased and reached a peak $(\mathrm{H}>3.0)$. Thereafter, bacterial diversity declined (SOM 10\%-12\%) (Figure 3). Meanwhile, fungal diversity was lower when SOM was between $2 \%$ and $4 \%$. The diversity of the fungal community increased 4-fold when the level of SOM increased up to between $6 \%$ and $8 \%$, and then declined when $\mathrm{SOM}>10 \%$ (Figure 4 ).

At the lowest level of $\mathrm{NO}_{3}-\mathrm{N}$, bacterial diversity was moderate $(2.75<\mathrm{H}<3.0)$ and gradually increased as $\mathrm{NO}_{3}-\mathrm{N}$ increased (Figure 3). Meanwhile, lower fungal diversity $(0.5<\mathrm{H}<1.0)$ was found in soils with the lowest $\mathrm{NO}_{3}-\mathrm{N}$ content 
(Figure 4). The diversity of fungal community increased sharply when the level of $\mathrm{NO}_{3}-\mathrm{N}$ increased.

\section{DISCUSSION}

Bacterial and fungal diversity and activity were used as measures to assess microbial responses to soil chemical factors under varying soil conditions. The present study found that there was a significant quadratic relationship between soil organic matter and bacterial and fungal activity and diversity. The availability of soil organic matter influenced the activity and diversity of the soil microbial community, with bacterial activity and diversity higher in soils containing high SOM in the range of $4 \%-8 \%$. This was similar for fungal activity and diversity that was higher in soils containing high SOM in the range 6\% and $8 \%$. However, bacterial and fungal activity and diversity did not increase in soils containing soil organic matter levels greater than $8 \%$. The results are broadly consistent with previous studies that have demonstrated that soil microbial diversity was positively correlated with SOM (Cookson, Murphy and Roper, 2008; J Garcia-Pausas and Paterson, 2011; Brennan and Acosta-Martinez 2017), although the decline with high SOM levels is less widely reported. In an experiment involving manipulation of SOM, a non-linear relationship was also found by Stark et al. (2008) when studying the effect of varying rates of $\mathrm{C}$ substrate on soil microbial biomass and activity.

A significant linear relationship also occurred between $\mathrm{N}$ compounds and bacterial and fungal activity and diversity. It was noted that the presence of $\mathrm{NO}_{3}-\mathrm{N}$ less than $10 \mathrm{ppm}$ (low level) in soil had resulted in low activity and diversity of these two microbial groups. A positive linear relationship between soil $\mathrm{N}$ compounds and the activity and diversity of bacteria and fungi was found. It appeared that higher activity and diversity of bacteria and fungi were related to the presence of moderate levels of $\mathrm{NO}_{3}-\mathrm{N}$ in the soils. This was likely linked with the role of bacterial and fungal community in $\mathrm{N}$ mineralisation. According to Kibblewhite et al. (2008), nitrogen cycling affects the delivery of ecosystem services driven by soil microbial community, so soil microbial activity may frequently be limited by $\mathrm{N}$ content in soil.

In previous studies, however, it was noted that there were inconsistent relationships between $\mathrm{N}$ compounds and activity and diversity of microbial community. Bengtsson et al. (2003) have found that microbial biomass and activity were weakly correlated with $\mathrm{N}$ mineralisation. Shi et al. (2006) suggested that the lack of correlation between microbial activity and the $\mathrm{N}$ mineralisation process was likely a result of changes in soil microbial composition. Also, in a study on the application of nitrogen fertilizer, Lupwayi et al. (2012) have found that the recommended rate of $\mathrm{N}$ application (50 $80 \mathrm{~kg} \mathrm{ha}^{-1}$ ) had no significant effects on soil microbial biomass and bacterial diversity.

In the present study, soil $\mathrm{pH}, \mathrm{CEC}$ and soil $\mathrm{Ca}: \mathrm{Mg}$ ratio had no significant effects on bacterial and fungal diversity. This result indicated that any effects of these chemical factors on the differences in soil microbial communities among the sites were small. Yet, Fierer and Jackson (2006) and Nicol et al. (2008) have found a strong correlation between soil $\mathrm{pH}$ and bacterial diversity. The diversity of soil bacterial communities on a global scale are higher in neutral soils and lower in acidic soils (Fierer and Jackson, 2006). Lauber et al. (2008) and Wakelin et al. (2008) also concluded that soil $\mathrm{pH}$ is involved in shaping the diversity of bacterial community, because bacterial communities often co-vary with shift of soil $\mathrm{pH}$, whereas diversity of fungal communities is mainly affected by a shift in soil nutrient status. However, some other previous studies have found a poor correlation between fungal community and soil $\mathrm{pH}$ by considering that fungal communities exhibit a wider range of $\mathrm{pH}$ for optimal growth (Lauber et al. 2008; Rousk et al. 2010).

The present study found a weak correlation, or no correlation, between bacterial and fungal activity and diversity and CEC, and between bacterial and fungal activity and diversity and $\mathrm{Ca}: \mathrm{Mg}$ ratio. This was likely because the heterogeneity of the data of chemical parameters among sites was relatively high, whereas the response data of activity and diversity of bacteria and fungi were relatively homogenous among sites. Stark et al. (2008) explain that poor correlations between soil microbial activity and soil chemical characteristics can occur due to the masking of responses by other soil and environmental factors that have greater effects on soil microbial characteristics.

\section{CONCLUSIONS}

Of all soil chemical characteristics measured in the current study, the study provides evidence that SOM plays an important role in affecting soil microbial activity and diversity under either untreated (natural) or treated conditions, and therefore this soil component cannot be ignored. Despite having significant relationships with soil microbial activity and diversity, soil salinity (EC) and $\mathrm{N}$ compound 
effects can be different among sites and therefore can possibly result in weak correlations with soil microbial activity and diversity. The chemical characteristics such as $\mathrm{EC}$ and $\mathrm{N}$ compounds together with other chemical properties (i.e. $\mathrm{pH}$, CEC, Ca:Mg ratio) can therefore be ruled out.

\section{ACKNOWLEDGEMENTS}

This research was supported by grant from The School of Graduate Research, Central Queensland University, Australia and Directorate General of Higher Education of the Republic of Indonesia. The authors thank Dr Melinda McHenry for her assistance with fieldwork and in proof reading, and Hamka Bahas for his help in statistical analyses.

\section{REFERENCES}

Bengtsson G, P Bengtson and KF Månsson. 2003. Gross nitrogen mineralization-, immobilization-, and nitrification rates as a function of soil $\mathrm{C} / \mathrm{N}$ ratio and microbial activity. Soil Biol Biochem 35: 143-154. doi: 10.1016/S0038-0717(02)00248-1.

Brennan EB and V Acosta-Martinez. 2017. Cover cropping frequency is the main driver of soil microbial changes during six years of organic vegetable production. Soil Biol Biochem 109: 188-204. doi: 10.1016/ j.soilbio.2017.01.014.

Cass A. 1998. Measuring and Managing Chemical ImpedimentsTo Growth. Ryan Publications.

Classen AT, SI Boyle, KE Haskins, ST Overby and SC Hart. 2003. Community-level physiological profiles of bacteria and fungi: plate type and incubation temperature influences on contrasting soils. FEMS Microbiol Ecol 44: 319-328. doi: 10.1016/S01686496(03)00068-0.

Coleman DC, DA Crossley Jr and PF Hendrix. 2004. Fundamentals of Soil Ecology. $2^{\text {nd }}$ edition. Academic Press, Burlington, London. doi: 10.1016/B978012179726-3/50004-6.

Cookson WR, DV Murphy and MM Roper. 2008. Characterizing the relationships between soil organic matter components and microbial function and composition along a tillage disturbance gradient. Soil Biol Biochem 40: 763-777. doi: 10.1016/ J.SOILBIO.2007.10.011.

Doran JW and MR Zeiss. 2000. Soil health and sustainability: managing the biotic component of soil quality. Applied Soil Ecol 15: 3-11. doi: 10.1016/S0929.

Falcon MF, Fox RL and EE Trujillo. 1984. Interaction of soil $\mathrm{pH}$, nutrients and moisture on phytophthora root rot of avocado. Plant Soil 81: 165-176. doi: 10.1007/ BF02197148.

Fierer N and RB Jackson. 2006. The diversity and biogeography of soil bacterial communities. Proceedings of the National Academy of Sciences of the United States of America 103: 626-631. Available at: http://www.pnas.org/content/103/3/626.abstract.
Garcia-Pausas J and E Paterson. 2011. Microbial community abundance and structure are determinants of soil organic matter mineralisation in the presence of labile carbon. Soil Biol Biochem 43: 1705-1713. doi: 10.1016/J.SOILBIO.2011.04.016.

Grayston SJ, CD Campbell, RD Bardgett, JL Mawdsley, CD Clegg, K Ritz, BS Griffiths, JS Rodwell, SJ Edwards, WJ Davies, DJ Elston and P Millard. 2004. Assessing shifts in microbial community structure across a range of grasslands of differing management intensity using CLPP, PLFA and community DNA techniques. Appl Soil Ecol 25: 63-84. doi: 10.1016/S0929-1393(03)00098-2.

Haggag WM. 2002. Sustainable agriculture management of plant diseases. On Line J Biol Sci 2: 280-284. Available at: https://scialert.net/ archivedetails.php?issn=1727-3048\&issueno $=21$.

Heyman F, B Lindahl, L Persson, M Wikstrom and J Stenlid. 2007. Calcium concentration of soils affect suppressiveness against Aphanomyces root rot of pea. Soil Biol Biochem 39: 2222-2229. doi: 10.1016/j.soilbio.2007.03.022.

Insam $\mathrm{H}$ and $\mathrm{M}$ Goberna. 2004. Use of Biolog ${ }^{\circledR}$ for the Community Level Physiological Prifiling (CLPP) of environmetal samples. Molec Micro Ecol Man $2^{\text {nd }}$ Ed 4: 853-860. doi: 10.1007/978-1-4020-21770401.

Isbel R. 1997. The Australian Soil Classification. 4. CSIRO publishing.

Kibblewhite MG, K Ritz and MJ Swift. 2008. Soil health in agricultural systems. Phylosophical T Roy Soc $B$ 363: 685-701. doi: 10.1098/rstb.2007.2178.

Lal R. 2011. Soil health and climate change: An overview. In: BP Singh, AL Cowie and KY Chan (eds). Soil Health and Climate Change. Springer-Verlag Berlin Heidelberg, pp. 3-24.

Lauber CL, MS Strickland, MA Bradford and N Fierer. 2008. The influence of soil properties on the structure of bacterial and fungal communities across land-use types. Soil Biol Biochem 40: 24072415. doi: 10.1016/J.SOILBIO.2008.05.021.

Lupwayi NZ, GP Lafond, N Ziadi and CA Grant. 2012. Soil microbial response to nitrogen fertilizer and tillage in barley and corn. Soil Till Res 118: 139146. doi: 10.1016/J.STILL.2011.11.006.

McLean EO. 1982. Soil pH and lime requirement. In AL Page (ed). Methods of Soil Analysis. Part 2. Chemical and Microbiological Properties. $2^{\text {nd }}$ edn. American Society of AGronomy Inc., Madison, Wisconsin, USA.

Nannipieri P and L Badalucco. 2003. Biological processes. In: DK Bembi and R Nieder (eds), Processes in the Soil-Plant System: Modelling Concepts and Applications. The Haworth Press, Binghamton, New York. 727 p.

Nelson DW and LE Sommers. 1982. Total carbon, organic carbon, and organic matter. In: AL Page (ed), Methods of Soil Analysis. Part 2. Chemical and Microbiological Properties. $2^{\text {nd }}$ edn. American Society of Agronomy Inc., Madison, Wisconsin, USA. 


\section{J Trop Soils, Vol. 24, No. 1, 2019: 43-51}

Nicol GW, S Leininger, C Schleper and JI Prosser. 2008. The influence of soil $\mathrm{pH}$ on the diversity, abundance and transcriptional activity of ammonia oxidizing archaea and bacteria. Environ Microbiol 10: 2966-2978. doi: doi:10.1111/j.14622920.2008.01701.x.

Rousk J, E Baath, PC Brookes, CL Lauber, C Lozupone, JG Caporaso, R Knight and N Fierer. 2010. Soil bacterial and fungal communities across a $\mathrm{pH}$ gradient in an arable soil. ISME J 4: 1340-1351. doi: 10.1038/ismej.2010.58.

Shi W, H Yao and D Bowman. 2006. Soil microbial biomass, activity and nitrogen transformations in a turfgrass chronosequenc. Soil Biol Biochem 38: 311-319. doi: 10.1016/J.SOILBIO.2005.05.008.

Stark CH, LM Condron, M O'Callaghan, A Stewart and HJ Di. 2008. Differences in soil enzyme activities, microbial community structure and short-term nitrogen mineralisation resulting from farm management history and organic matter amendments. Soil Biol Biochem 40: 1352-1363. doi: 10.1016/J.SOILBIO.2007.09.025.

Thomas GW. 1982. Exchangeable cations. In: AL Page (ed.). Methods of Soil Analysis. Part 2. Chemical and Microbiological Properties. $2^{\text {nd }}$ edn. American Society of Agronomy Inc., Madison, Wisconsin, USA.

Tu L, G Chen, Y Peng, H Hu, T Hu, J Zhang, X Li and L Liu Y Tang. 2014. Soil biochemical responses to nitrogen addition in a bamboo forest. PLOS ONE 9: 1-8. doi: 10.1371/journal.pone.0102315.

Wakelin SA, LM Macdonald, SL Rogers, AL Gregg, TP Bolger and JA Baldock. 2008. Habitat selective factors influencing the structural composition and functional capacity of microbial communities in agricultural soils. Soil Biol Biochem 40: 803-813. doi: 10.1016/J.SOILBIO.2007.10.015.

Whalley WR, E Dumitru and AR Dexter. 1995. Biological effects of soil compaction. Soil Till Res 35: 53-68. doi: 10.1016/0167-1987(95)00473-6. 